\title{
The human battle with glioblastoma multiforme: A true challenge
}

\author{
Christ Ordookhanian*, Samer S. Ghostine and Paul E. Kaloostian \\ University of California, Riverside School of Medicine, 900 University Avenue Riverside, California 92521, USA
}

Glioblastoma Multiforme(GBM), the most common primary brain tumor, is a malignant tumor often forming in the cerebral hemisphere of the brain. This tumor originates from mutated astrocytes, which are cells that begin to reproduce uncontrollably and are supplied generously via nearby blood vessels. Glioblastomas are derived from healthy brain cells, thus are capable of living and flourishing within the cerebral cavity. Glioblastomas take on two forms, primary and secondary, which are distinguished by their respective rate of growth. Primary glioblastomas are aggressive and form rapidly, while secondary giloblastomas proliferate at slower rates and transform into aggressive tumors from more initially benign lesions [1-4].

In 2017 thus far, there have been an upwards of 138,000 malignant brain tumor cases, in which $15.4 \%$ are GBM tumors and $3 \%$ are brain tumors arising during childhood. Patients with glioblastoma often present with primary chief complaints of headache, nausea, drowsiness, and vomiting. Depending on the volume of the tumor and exact location within the central nervous system, additional symptoms such as weakness, memory loss and speech impairment may also be observed. Please note that not all headaches indicate that someone will have a GBM. In fact, most headaches are not indicative of GBM and are likely related to myofascial inflammation of the neck muscles and/ or migraines [5-8].

The diagnosis of glioblastoma is conducted by a neurologist or neurological surgeon in which diagnostic imaging is utilized to visualize the exact location of the tumor, size and shape. Classically, patients have undergone a Computed Tomography (CT) scan of the head showing a lesion in the brain. Magnetic resonance imaging (MRI) is then obtained to identify more precisely the size, shape, location and anatomical morphology of the brain tumor. MRI imaging also reveals protruding regions of the tumor such as the tentacles of tumor spread and growth, as well as the three-dimensional analysis of the tumor's proliferation. Diffusion Tensor Imaging (DTI) is commonly used to identify tumor infiltration into the parenchyma of the brain by providing a picture of the actual neurons of the brain in relation to the tumor. This imaging modality, along with neuronavigation guidance, are used intraoperatively during resection of the tumors for maximal patient safety and outcome [9-20].

Glioblastoma's are characterized as World Health Organization (WHO) grade IV tumors, which are tremendously aggressive and often causes mortality within an average one year of onset. GBM is by far the most polymorphic neoplastic tumor with undefined spherical boarders often observed crossing from one hemisphere to the other hemisphere on MRI and CT scans. Treatment of GBM involves the surgical debulking of the tumor if in a non-high-risk location of the brain. In complex cases where location of the tumor creates surgical difficulties, the tumor may not be removed at all. Instead, radiation therapy can be utilized to kill as many tumor cells as possible. In addition, chemotherapeutic agents such as Temozolomide can also be utilized to halt or reduce the spread of the tumor. Additionally, combination of surgical debulking, whole brain radiation therapy, and chemotherapy regimen used adjunctively provide the best current outcomes. Recently, electric field therapy has become an option in which electrical fields are used to target the tumor cells while leaving healthy cells unharmed. With the severity of cases varying from patient to patient, many of the above treatments can serve as valid and beneficial treatments to GBM. Current research with formation of vaccines is underway with hopes of eradicating this terrible human cancer. Novel techniques investigating creative therapeutics involving stem cells, nanotechnology, and molecular medicine are underway which all strive for tumor selectivity. Depending on treatment route chosen, prognosis of the patient's recovery is generally quite poor within one year after treatment. The future of GBM resides in the development of novel treatments and medications that can selectively target tumor cells as opposed to normal brain cells [21-31].

\section{References}

1. Brodbelt A, Greenberg D, Winters T, Williams M, Vernon S, et al. (2015) Glioblastoma in England: 2007-2011. Eur J Cancer 51: 533-542. [Crossref]

2. Chakrabarti I, Cockburn M, Cozen W, Wang YP, Preston-Martin S (2005) A populationbased description of glioblastoma multiforme in Los Angeles County, 1974-1999. Cancer 104: 2798-2806.

3. Gatenby RA (2009) A change of strategy in the war on cancer. Nature 459: 508-509. [Crossref]

4. Kvale EA, Murthy R, Taylor R, Lee JY, Nabors LB (2009) Distress and quality of life in primary high-grade brain tumor patients. Support Care Cancer 17: 793-799. [Crossref]

5. Lawrence YR, Mishra MV, Werner-Wasik M, Andrews DW, Showalter TN, et al. (2012) Improving prognosis of glioblastoma in the 21 st century: who has benefited most? Cancer 118: 4228-4234. [Crossref]

6. Natalwala A, Bharkhada V, Noel G, Cruickshank G (2011) Comparison of time taken from initial presentation to histological diagnosis of Glioblastoma Multiforme (GBM) in Birmingham, United Kingdom and Strasbourg, France. Clin Neurol Neurosurg 113: 358-361. [Crossref]

7. Stark AM, Nabavi A, Mehdorn HM, Blömer U (2005) Glioblastoma multiforme-report of 267 cases treated at a single institution. Surg Neurol 63: 162-169. [Crossref]

8. Rahman M, Hoh B, Kohler N, Dunbar EM, Murad GJ (2012) The future of glioma treatment: stem cells, nanotechnology and personalized medicine. Future Oncol 8: 1149-1156. [Crossref]

Correspondence to: Christ Ordookhanian, University of California, Riverside School of Medicine, 900 University Avenue Riverside, California 92521, USA, E-mail: cordo002@ucr.edu

Received: July 20, 2017; Accepted: August 08, 2017; Published: August 10, 2017 
9. Bohman LE, Swanson KR, Moore JL, Rockne R, Mandigo C, et al. (2010) Magnetic resonance imaging characteristics of glioblastoma multiforme: implications for understanding glioma ontogeny. Neurosurgery 67: 1319-1327. [Crossref]

10. Cancer Genome Atlas Research N (2008) Comprehensive genomic characterization defines human glioblastoma genes and core pathways. Nature 455: 1061-1068. [Crossref]

11. Crespo I, Vital AL, Gonzalez-Tablas M, Patino Mdel C, Otero A, et al. (2015) Molecular and Genomic Alterations in Glioblastoma Multiforme. Am J Pathol 185: 1820-1833. [Crossref]

12. Halshtok Neiman O, Sadetzki S, Chetrit A, Raskin S, Yaniv G, Hoffmann C (2013) Perfusion-weighted imaging of peritumoral edema can aid in the differential diagnosis of glioblastoma mulltiforme versus brain metastasis. Isr Med Assoc J 15: 103-105. [Crossref]

13. Lee M, Woo B, Kuo MD, Jamshidi N, Kim JH (2017) Quality of radiomic features in glioblastoma multiforme: Impact of semi-automated tumor segmentation software. Korean J Radiol 18: 498-509. [Crossref]

14. Napolitano M, Vaz G, Lawson TM, Docquier MA, van Maanen A, et al. (2014) Glioblastoma surgery with and without intraoperative MRI at 3.0T. Neurochirurgie 60: 143-150. [Crossref]

15. Litofsky NS, Bauer AM, Kasper RS, Sullivan CM, Dabbous OH, Glioma Outcomes Project I (2006) Image-guided resection of high-grade glioma: patient selection factors and outcome. Neurosurg Focus 20: E16. [Crossref]

16. Norton L, Simon R (1977) Tumor size, sensitivity to therapy, and design of treatment schedules. Cancer Treat Rep 61: 1307-1317. [Crossref]

17. Rockne R, Rockhill JK, Mrugala M, Spence AM, Kalet I, et al. (2010) Predicting the efficacy of radiotherapy in individual glioblastoma patients in vivo: a mathematical modeling approach. Phys Med Biol 55: 3271-3285. [Crossref]

18. Sagehorn EG (1980) Competency-that elusive quality. Am J Orthod 78: 341-345. [Crossref]

19. van Linde ME, Brahm CG, de Witt Hamer PC, Reijneveld JC, et al. (2017) Treatment outcome of patients with recurrent glioblastoma multiforme: a retrospective multicenter analysis. J Neurooncol. [Crossref]

20. Veiseh O, Sun C, Gunn J, Kohler N, Gabikian P, et al. (2005) Optical and MRI multifunctional nanoprobe for targeting gliomas. Nano Lett 5: 1003-1008. [Crossref]
21. Blumenthal DT, Gorlia T, Gilbert MR, Kim MM, Burt Nabors L, et al. (2017) Is more better? The impact of extended adjuvant temozolomide in newly diagnosed glioblastoma: a secondary analysis of EORTC and NRG Oncology/RTOG. Neuro Oncol. [Crossref]

22. Chamberlain MC (2006) Treatment options for glioblastoma. Neurosurg Focus 20 E19. [Crossref]

23. Ding H, Inoue S, Ljubimov AV, Patil R, Portilla-Arias J, et al. (2010) Inhibition of brain tumor growth by intravenous poly $\left(\hat{\mathrm{I}}^{2}-\mathrm{L}-\right.$ malic acid) nanobioconjugate with $\mathrm{pH}$ dependent drug release. Proc Natl Acad Sci U S A 107: 18143-18148. [Crossref]

24. Field KM, Drummond KJ, Yilmaz M, Tacey M, Compston D, et al. (2013) Clinical trial participation and outcome for patients with glioblastoma: multivariate analysis from a comprehensive dataset. J Clin Neurosci 20: 783-789. [Crossref]

25. Gil-Salu JL, Roman P, Benitez E, Maestro E, Perez-Requena J, Lopez-Escobar M (2004) Survival analysis following the addition of temozolomide to surgery and radiotherapy in patients with glioblastoma multiforme. Neurocirugia (Astur) 15: 144150. [Crossref]

26. Hottinger AF, Yoon H, DeAngelis LM, Abrey LE (2009) Neurological outcome of long-term glioblastoma survivors. J Neurooncol 95: 301-305. [Crossref]

27. Kong J, Wang F, Teodoro G, Cooper L, Moreno CS, et al. (2013) High-performance computational analysis of glioblastoma pathology images with database support identifies molecular and survival correlates. Proceedings (IEEE Int Conf Bioinformatics Biomed). [Crossref]

28. Kreuter J, Gelperina S (2008) Use of nanoparticles for cerebral cancer. Tumori 94 271-277. [Crossref]

29. Rusthoven CG, Koshy M, Sher DJ, Ney DE, Gaspar LE, et al. (2016) Combinedmodality therapy with radiation and chemotherapy for elderly patients with glioblastoma in the temozolomide era: A national cancer database analysis. JAMA Neurol 73: 821-828. [Crossref]

30. Smoll NR, Schaller K, Gautschi OP (2013) Long-term survival of patients with glioblastoma multiforme (GBM). J Clin Neurosci 20: 670-675. [Crossref]

31. Wu CC, Wang TJ, Jani A, Estrada JP, Ung T, et al. (2016) A modern radiotherapy series of survival in hispanic patients with glioblastoma. World Neurosurg 88: 260-269. [Crossref]

Copyright: (C2017 Ordookhanian C. This is an open-access article distributed under the terms of the Creative Commons Attribution License, which permits unrestricted use, distribution, and reproduction in any medium, provided the original author and source are credited. 